\title{
A new species of Calomys Waterhouse (Rodentia, Sigmodontinae) from the Cerrado of Central Brazil
}

\author{
Cibele R. Bonvicino ${ }^{1,2}$, José F. S. Lima ${ }^{3} \&$ Francisca C. Almeida ${ }^{2}$
}

\author{
1 Corresponding author. \\ ${ }^{2}$ Divisão de Genética, Instituto Nacional de Câncer. Praça da Cruz Vermelha 23, 20230-130 Rio de Janeiro, Rio de Janeiro, \\ Brasil. E-mail: cibelerb@inca.gov.br \\ ${ }^{3}$ Departamento de Genética, Universidade Federal do Paraná. Caixa Postal 19071, Curitiba 81531-970, Paraná, Brasil. \\ Bolsista do CNPq/Plano Sul. E-mail: jflima@hotmail.com
}

\begin{abstract}
A new Brazilian Calomys Waterhouse, 1837 species is described based on morphologic and karyologic data. This species is endemic to the Cerrado of Central Brazil and allopatric with all other species of the genus Calomys. Its chromosome complement $(2 n=46, A N=66)$ is different from those described in other Calomys species. Morphometric analysis significantly distinguished this new species from other Calomys of the Brazilian fauna like C. callosus (Renger, 1830), C. expulsus (Lund, 1841) and C. tener (Winge, 1887) and placed it among the large-sized Calomys.
\end{abstract}

KEY WORDS. Brazilian Cerrado, Calomys, karyotype, morphology, new species.

\begin{abstract}
The genus Calomys Waterhouse, 1837 is widespread along the southern half of South America (HershKovitz 1962). Although extensively studied (HershKovitz 1962, Massoia et al. 1968, Pearson \& Patton 1976, Baskin 1978, Corach et al. 1988, Provensal \& Polor 1993, Braun 1993) some problems, involving the taxonomic limits of Calomys species remain to be resolved. The latest world mammal check list attributed 9 species to the genus Calomys, three of which, Calomys callosus (Rengger, 1830), Calomys tener (Winge, 1887) and Calomys laucha (Fisher, 1814), occurring in Brazil (Musser \& CARLETON 1993). Calomys expulsus (Lund, 1841) was considered a junior synonymous of C. callosus (Musser \& CARLETON 1993) while other authors considered it a subspecies of C. callosus (Hershrovitz 1962) or a valid species (CABRera 1961). Recently, Bonvicino \& Almeida (2000), based on morphologic and karyologic data, showed that C. callosus and C. expulsus are valid species.

These taxonomic problems lead to uncertainty in species identification in ecologic studies (Karimi et al. 1976, Alho \& Pereira 1985, Alho et al. 1986, Mares et al. 1986) and karyologic studies (e.g. Brum-Zorrilla et al. 1990, Yonenaga 1975). Five different karyotypes were described for Calomys specimens of Brazil: $2 \mathrm{n}=64$ (Kasahara \& Yonenaga-YaSSUdA 1984); $2 \mathrm{n}=66$, $\mathrm{AN}=66 ; 2 \mathrm{n}=66, \mathrm{AN}=68$ (Bonvicino \& Almeida 2000); $2 \mathrm{n}=36$, $\mathrm{AN}=68$ (GeISE et al. 1996) and $2 \mathrm{n}=46, \mathrm{AN}=66$ (LIMA \& KASAHARA 1999, 2001; FAGUNDEs et al. 2000). These studies indicated that Calomys is a specious genus, as suggested by the association of karyologic and taxonomic studies.
\end{abstract}

Here a new species of Calomys endemic to the Cerrado of Brazil with karyologic and morphologic comparisons with other Brazilian Calomys species is described.

\section{Calomys tocantinsi sp. nov.}

Holotype. Brasil, Tocantins: Formoso do Araguaia (Rancho Beira Rio, $33 \mathrm{~km} \mathrm{SW}, 11^{\circ} 47^{\prime} \mathrm{S}$ and $49^{\circ} 45^{\prime} \mathrm{W}$ ), MN62733 (former number ZUT 54, field number FSL 124), an adult male conserved as skin and skeleton, plus karyotype, José Fernando de Sousa Lima leg.

Paratypes. MN 62742, MN 62743, MN 62736, MN 62737, MN 62733, MN 62739, MN 62738, MN 62732, MN 62731, ZUT $46,48,56,58,64,65,74,45,62,66,72$ and 73 from type locality.

Type locality. Rancho Beira Rio, 33 km SW Formoso do Araguaia, state of Tocantins, Brazil (Fig. 1).

Etymology. tocantinsi refers to Tocantins state, the first Brazilian state where this species was collected.

Distribution. known from type locality, Rio Tocantins bank municipality of Porto Nacional and Ilha do Bananal in the Araguaia National Park. This species also occur in Vila Rica and Cocalinho, state of Mato Grosso (karyotyped specimens; FAGUNDES et al. 2000).

Diagnosis. A large-sized Calomys with tail shorter than head-body, dorsal coloration brownish-grey with a darker central and longitudinal wide stripe, palatal bridge broad and long, and a diploid number of 46 chromosomes. 


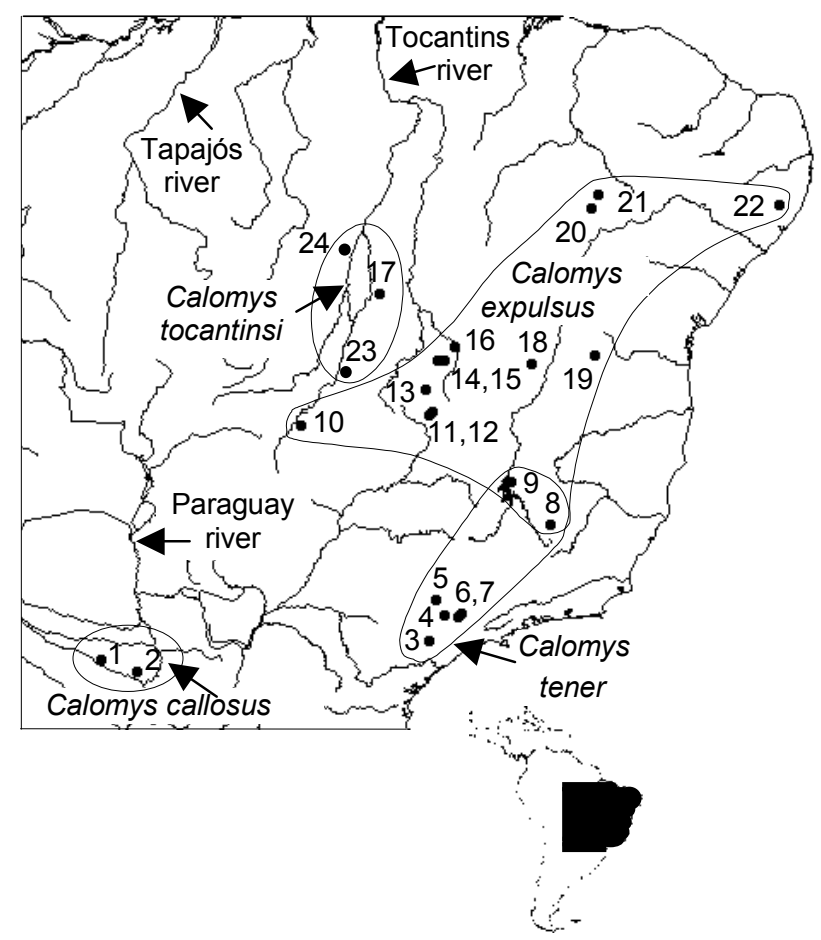

Figure 1. Localities of occurrence of Calomys tocantinsi sp. nov., C. expulsus, C. tener and C. callosus. Paraguay: Dept. Presidente Hayes (1) 213 km NW Villa Hayes by rd, (2) 69 km NW Villa Hayes by rd; Brazil: São Paulo: (3) Itapetininga, (4) Itirapina, (5) Rio Claro, (6) Campinas, (7) Pedreira; Minas Gerais: (8) Lagoa Santa, (9) Três Marias; Mato Grosso: (10) Baliza, (23) Cocalinho, (24) Vila Rica; Distrito Federal (11) Brasília; Goiás (12) Corumbá de Goiás, (13) Mimoso de Goiás, (14) Cavalcante, (15) Alto Paraíso, (16) Teresina de Goiás; Tocantins (17) Formoso do Araguaia; Bahia (18) Jaborandi, (19) Caetité; Piauí (20) Coronel José Dias, (21) São João do Piauí; Pernambuco (22).

\section{Description}

External morphology. A large-sized Calomys, with tail shorter than head-body. The overall dorsal pelage coloration of head and body is brownish-grey. Pelage coloration is darker, longitudinally along mid-dorsum, from muzzle to base of tail. Inner and external sides of pinnae covered with short dark hairs. Patch of completely white hairs at posterior base of ears. Two kinds of hairs are evident in dorsum: a longer and totally dark hair and a slightly shorter and bicoloured (dark with a subapical brownish band) overhair. Body side colouration is lighter than dorsum, with a defined limit with the ventral white pelage. The entirely dark hairs are very scarce at sides and absent in ventral pelage. Subapical bands of overhairs are longer towards laterals where they become paler, providing an overall light brown yellowish colouration. Ventral hairs are white at tip and grey at base. Vibrissae are dark except at vicinity of muzzle tip where some vibrissae are lighter. Tail bicoloured covered with light hairs in ventral part and dark hairs in the dorsal part. Dorsal surface of fore- and hind feet covered with white hairs. Toes covered with white hairs, with ungual tuffs of white hairs covering claws.

Mean, range and sample size of external measurements, in millimetres: females - HB 90.1 (77-105, $\mathrm{n}=10)$, T 66.6 (60-75, $\mathrm{n}=10)$, F $21.2(22-22.5, \mathrm{n}=10)$, E $17(13.5-21, \mathrm{n}=10)$, W 0.1 g (12.5-27.8, $\mathrm{n}=10)$; males: HB $91.8(79-116, \mathrm{n}=8)$, T 68.4 $(61.5-75, \mathrm{n}=8)$, F $21.2(20-22, \mathrm{n}=8)$, E $16.5(14-18, \mathrm{n}=8), \mathrm{W}$ $25.3 \mathrm{~g}(14.6-31, \mathrm{n}=8)$.

Cranial morphology. The rostrum is relatively narrow and short. The zygomatic plate is broad with its anterior margin projecting forward and partially overlapping with the nasolacrimal capsule forming a conspicuous zygomatic notch. Zygomatic arches are robust with distinctive jugals. The interorbital region is wide (as wide as rostrum) with an incipient supraorbital ridge resulting in a more elongated braincase when viewed from above. The braincase is narrow and elongated. The interparietal is relatively wide, its width covering almost the entire border of the parietal. Incisive foramina are long (spannig about $80 \%$ of diastema length) and parallel-sided, reaching the protocone of first superior molar. The bony palatal length exceeding the end of superior molar row, projecting beyond it to a distance equal to M3 length. Posteropalatal pits are large, usually with minor associate foramina. Anterior palatine foramina (see HershKovitz 1962) present at level of anterior half of M2. The mesopterygoid fossa is dorsally perforated by sphenopalatine vacuities of moderate size. The large parapterygoid plates are heavily ossified and lacking fontanellae. A groove usually marks the rear of the plate at the crossing of the infraorbital branch of the stapedial artery before entering the alisphenoid canal. Subsquamosal fenestrae present and spacious, slightly smaller than postglenoid foramina, with narrow hamular processes. Large ectotympanic bullae covering almost the entire surface of periotic bones, exposing a narrow segment of each periotic bone. Lateral walls of mastoids thin and perforated by a medium-sized fenestra. Squamosal alisphenoid grooves are present. Cranial measurements are shown in table II.

Dental Morphology. Incisors are opisthodont. The anteromedium flexus is distinct and deep in young animals, forming prominent anterolingual and anterolabial conules. The M2 closely resembles the M1 except for lacking a procingulum. The M3 is almost circular and its length is about two-thirds the length of M2.

Karyotype. Karyologic analysis of Calomys tocantinsi showed $2 \mathrm{n}=46, \mathrm{AN}=66$ (Fig. 2, Tab. I). The autosome complement comprises 11 biarmed pairs and 11 acrocentric pairs. The $\mathrm{X}$ chromosome is a medium sized metacentric and the $\mathrm{Y}$ chromosome is a small sized acrocentric.

Ecological comments. This species was collected in (1) gallery forest (found along rivers) in the limit with campo cerrado (grassland with scarce scrub cover), (2) cerradão (evergreen vegetation around $10 \mathrm{~m}$ high), (3) campo sujo (dry grassland with scattered scrub ligneous vegetation), (4) cerrado sensu stricto (grassland with scrub cover) and inside edifications near natural vegetation. FAGUNDEs et al. (2000) found this species in trasitional areas between Amazonian rain forest and "cerrado" in Central Brazil. Calomys tocantinsi was collected in sympatry with Bolomys lasiurus, Oligoryzomys sp. and Rattus rattus in type locality. 
Table I. Data on Calomys karyotypes. Taxa are valid species names presently attributed to karyotypic data and names in brackets are the original names attributed by quoted authors. (2n) Diploid number, (AN) autossomic arms. Source: (1) MASSOIA et al. (1968), (2) GARDNER \& PATTON (1976), (3) BRUM-ZORRILLA et al. (1990), (4) BONVICINO \& ALMEIDA (2000), (5) KASAHARA \& YONENAGA-YASSUDA (1984), (6) PEARSON \& PATTON (1976), (7) GEISE et al. (1996), (8) GARDENAL et al. (1977), (9) YONENAGA (1975), (10) FAGUNDES et al. (2000) and (ts) this study.

\begin{tabular}{|c|c|c|c|c|}
\hline Taxa & $2 n$ & AN & Locality & Source \\
\hline C. callosus & 36 & 48 & 213 km NW Vila Hayes, Paraguay & 2,6 \\
\hline C. musculinus & 38 & 56 & Chucril, Cordoba, Argentina & 1 \\
\hline Calomys sp.(C. expulsus) & 36 & 66 & Lagoa Santa, Minas Gerais, Brazil & 6 \\
\hline C. lepidus & 36 & 68 & Junin and Puno, Peru & 6 \\
\hline C. fecundus & 50 & 66 & 160 km N Trinidad, Beni, Bolivia & 2 \\
\hline Calomys sp.(C. laucha) & 56 & 60 & Artigas, Uruguay & 3 \\
\hline C. laucha & 62 & 72 & Parque Pereyra, Buenos Aires, Argentina & 1,3 \\
\hline Calomys sp.(C. callosus) & 64 & & Rio Grande do Sul, Brazil & 5 \\
\hline Calomys sp.(C. laucha) & 64 & 70 & Laboulaye, Cordoba, Argentina; Laguna Negra, Uruguay & 3,8 \\
\hline C. sorellus & 64 & 68 & Deptos from Ancash to Puno, Peru & 2 \\
\hline C. sorellus (C. laucha) & 64 & 68 & $\begin{array}{l}\text { Esquina, Corrientes, Argentina; Concordia, M. Chico, Laguna Negra, } \\
\text { Colonia Palma, Bela Vista, Uruguay }\end{array}$ & 3 \\
\hline Calomys sp.(C. laucha) & 64 & 76 & Laguna Larga, Cordoba, Argentina & 3 \\
\hline C. tener (Calomys sp.) & 66 & 66 & São Paulo, Brazil & 9 \\
\hline C. tener & 66 & 66 & Goiás and São Paulo, Brazil & 4 \\
\hline Calomys tener (C. expulsus) & 66 & 66 & Minas Gerais, Brazil & 7 \\
\hline C. expulsus & 66 & 68 & Bahia and Goiás, Brazil & 4 \\
\hline C. expulsus & 66 & 68 & Piauí, Brazil & ts \\
\hline C. tocantinsi sp. nov. & 46 & 66 & Formoso do Araguaia, Tocantins, Brazil & ts \\
\hline C. tocantinsi sp. nov. & 46 & 66 & Vila Rica and Cocalinho, Mato Grosso, Brazil & 10 \\
\hline
\end{tabular}

\section{Comparisons}

Cranial measurements of C. tener, C. expulsus, C. callosus and Calomys tocantinsi are showed in table II. The Canonical Discriminant Analysis discriminated the four species (Likelihood F test with successive roots removed: Wilks' lambda $=0.0075, \mathrm{~F}=10.95$, d.f. $=39, \mathrm{p}<0.0001$ with all three functions; Wilks' lambda $=0.078, \mathrm{~F}=7.52$, d.f. $=24, \mathrm{p}=0.0001$ for the first function removed; and Wilks' lambda $=0.390, \mathrm{~F}=5.11$, d.f. $=11, \mathrm{p}<0.0001$ for the two first functions removed). This analysis clearly separated Calomys tocantinsi $(\mathrm{N}=6)$ and C. tener $(\mathrm{N}=9)$, and grouped $C$. expulsus $(\mathrm{N}=21)$ with $C$. callosus $(\mathrm{N}=$ 14 ) in the first canonical function (accounting for $62.7 \%$ of the total variance) while C. expulsus was separated from $C$. callosus in the third canonical function (accounting for $10.45 \%$ of the total variance; Fig. 3A, B).

The Principal Component Analysis separated the species in two groups, one of small-sized species formed by $C$. tener and another including the large-sized species C. callosus, $C$. expulsus and Calomys tocantinsi (Fig. 3C). The first principal component is generally interpreted as a size vector and

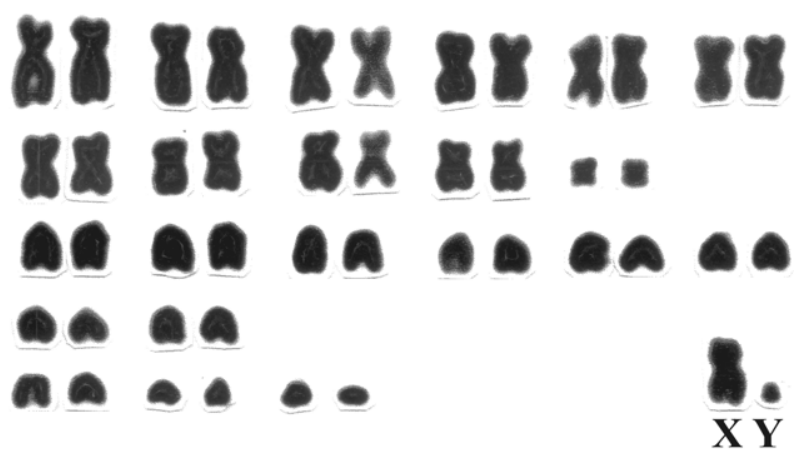

Figure 2. Conventional Giemsa coloration of Calomys tocantinsi sp. nov. karyotype.

accounted for $72.5 \%$ of the explained variance. In view of these results, analysis of variance was carried out only with large- 
Table II. Mean, standard deviations, range of cranial measurements, and sample size of Calomys species. See Voucher specimens and methods to cranial variable abbreviations. (N) Sample size.

\begin{tabular}{|c|c|c|c|c|c|}
\hline VAR & $\begin{array}{c}\text { C. tocantinsi } \\
(\mathrm{N}=11 \text { females })\end{array}$ & $\begin{array}{c}\text { C. tocantinsi } \\
(\mathrm{N}=8 \text { males })\end{array}$ & $\begin{array}{l}\text { C. expulsus } \\
(\mathrm{N}=21)\end{array}$ & $\begin{array}{l}\text { C. callosus } \\
(\mathrm{N}=27)\end{array}$ & $\begin{array}{l}\text { C. tener } \\
(\mathrm{N}=10)\end{array}$ \\
\hline GSL & $24.8 \pm 1.3,22.9-26.0(8)$ & $25.0 \pm 1.6,24.2-28.6(7)$ & $25.46 \pm 1.31,28.2-23.7$ & $24.97 \pm 1.49,22.48-27.79$ & $22.1 \pm 0.9,23.5-21.0$ \\
\hline CIL & $22.5 \pm 1.6,19.7-24.3(10)$ & $23.5 \pm 1.8,20.9-26.5(8)$ & $23.68 \pm 1.24,26.2-22.2$ & $22.92 \pm 1.43,20.15-25.49$ & $19.9 \pm 0.7,21.0-18.8$ \\
\hline $\mathrm{BOC}$ & $5.9 \pm 0.2,5.6-6.3(11)$ & $6.0 \pm 0.3,5.7-6.6(8)$ & $5.79 \pm 0.20,6.2-5.5$ & $5.78 \pm 0.26,5.32-6.35$ & $5.1 \pm 0.3,5.5-4.7$ \\
\hline LD & $6.0 \pm 0.5,5.2-6.8(11)$ & $6.2 \pm 0.7,5.1-7.3(8)$ & $6.42 \pm 0.51,7.8-5.8$ & $6.20 \pm 0.46,5.33-7.16$ & $5.3 \pm 0.3,5.8-5.0$ \\
\hline PB & $4.7 \pm 0.3,4.2-5.3(11)$ & $4.9 \pm 0.5,4.2-5.9(8)$ & $4.23 \pm 0.30,4.8-3.7$ & $4.53 \pm 0.30,3.77-5.16$ & $3.7 \pm 0.3,4.2-3.5$ \\
\hline M1M & $5.1 \pm 0.2,4.7-5.4(11)$ & $5.2 \pm 0.3,4.8-5.6(8)$ & $5.3 \pm 0.3,5.9-4.9$ & & $4.5 \pm 0.2,4.9-4.2$ \\
\hline LIF & $4.8 \pm 0.4,4.2-5.4(11)$ & $5.3 \pm 0.4,4.6-5.9(8)$ & $5.6 \pm 0.4,6.5-4.9$ & $5.53 \pm 0.47,4.97-6.54$ & $4.6 \pm 0.3,5.1-3.8$ \\
\hline BIF & $1.6 \pm 0.1,1.4-1.9(11)$ & $1.8 \pm 0.2,1.5-2.1(8)$ & $1.7 \pm 0.2,2.2-1.5$ & $1.71 \pm 0.14,1.47-2.11$ & $1.5 \pm 0.1,1.7-1.3$ \\
\hline LM & $4.2 \pm 0.2,3.8-4.5(11)$ & $4.3 \pm 0.2,4.1-4.6(8)$ & $4.0 \pm 0.1,4.2-3.8$ & $4.06 \pm 0.14,3.86-4.41$ & $3.4 \pm 0.2,3.9-3.1$ \\
\hline BM1 & $1.3 \pm 0.1,1.2-1.4(11)$ & $1.3 \pm 0.1,1.2-1.4(8)$ & $1.17 \pm 0.1,1.4-1.1$ & $1.16 \pm 0.06,1.05-1.32$ & $0.98 \pm 0.07,1.1-0.9$ \\
\hline RL & $8.8 \pm 0.5,8.2-9.6(9)$ & $9.1 \pm 0.9,8.1-10.4(7)$ & $9.1 \pm 0.6,10.4-8.2$ & & $7.6 \pm 0.5,8.5-7.0$ \\
\hline BRO & $4.6 \pm 0.3,4.0-4.9(11)$ & $4.6 \pm 0.2,4.3-5.0(8)$ & $4.8 \pm 0.3,5.4-4.4$ & & $4.2 \pm 0.3,4.5-3.9$ \\
\hline ORL & $8.1 \pm 0.7,7.5-9.5(11)$ & $9.1 \pm 0.7,8.4-10.3(8)$ & $9.4 \pm 0.40,10.3-8.8$ & $9.00 \pm 0.59,7.97-10.87$ & $8.0 \pm 0.3,8.3-7.1$ \\
\hline LIB & $4.2 \pm 0.2,3.8-4.5(11)$ & $4.3 \pm 0.2,3.8-4.6(8)$ & $4.2 \pm 0.3,4.7-3.83$ & $4.19 \pm 0.20,3.84-4.53$ & $3.7 \pm 0.2,4.1-3.4$ \\
\hline ZB & $13.4 \pm 0.9,11.8-14.2(11)$ & $13.8 \pm 0.9,12.6-15.3(8)$ & $13.3 \pm 0.46,14.0-12.5$ & $13.24 \pm 0.56,12.29-14.44$ & $11.5 \pm 0.5,12.2-10.6$ \\
\hline BB & $10.7 \pm 0.3,9.9-11.1(10)$ & $10.9 \pm 0.3,10.5-11.2(8)$ & $10.8 \pm 0.3,11.4-10.2$ & $11.09 \pm 0.35,10.4-11.79$ & $9.8 \pm 0.3,10.4-9.5$ \\
\hline $\mathrm{CH}$ & $7.8 \pm 0.3,7.4-8.4(11)$ & $7.9 \pm 0.5,7.6-8.7(8)$ & $7.8 \pm 0.4,8.5-7.3$ & & $7.0 \pm 0.2,7.3-6.5$ \\
\hline BZP & $2.9 \pm 0.3,2.5-3.5(11)$ & $3.0 \pm 0.3,2.6-3.5(8)$ & $2.9 \pm 0.2, \quad 3.4-2.5$ & & $2.4 \pm 0.2,2.7-2.0$ \\
\hline
\end{tabular}

sized species. Only three cranial variables showed significant differences among species with analysis of variance and Bonferroni correction: $\mathrm{BB}(\mathrm{F}=13.86$, d.f. $=2, \mathrm{p}<0.0001)$, LM $(\mathrm{F}=20.43$, d.f. $=2, \mathrm{p}<0.0001)$ and $\mathrm{PB}(\mathrm{F}=11.48$, d.f. $=2$, $\mathrm{p}<0.0001)$. All three variables discriminated Calomys tocantinsi from $C$. expulsus and C. callosus with the Bonferroni test $(\mathrm{p}<$ 0.05) whereas only $\mathrm{PB}$ and $\mathrm{BB}$ distinguished C. expulsus from C. callosus.

The karyotype of Calomys tocantinsi $(2 \mathrm{n}=46, \mathrm{AN}=66)$ is different from all others previously reported in Calomys species (Tab. I) like C. expulsus $(2 \mathrm{n}=66, \mathrm{AN}=68)$ and C. tener $(2 \mathrm{n}=66$, $\mathrm{AN}=66)$, the other two species herein analysed which also inhabit the Cerrado of Central Brazil. Other species of the Brazilian fauna, Calomys sp. $(2 \mathrm{n}=36)$ and Calomys laucha (with several, attributed chromosome complements) are also karyotypically different from Calomys tocantinsi (Tab. I). This karyotype is also different from the ones attributed to $C$. callosus: $2 \mathrm{n}=36, \mathrm{AN}=66$ (Pearson \& Patton 1976) and $2 \mathrm{n}=50$, AN $=66$ (SAlazAR-Bravo et al. 2001). Interestingly, despite variation in diploid number from 36 to 66, these Brazilian Calomys show a small variation in AN, from 66 to 68 , in agreement with Lima \& KaSAHARA (2001) who suggested that Robertsonian rearrangements are the main mechanism involved in the karyologic differentiation of this group.

Despite karyotypic differences, Calomys tocantinsi, $C$. expulsus and C. callosus are similar in cranial measurements (Tab. II) while Calomys tocantinsi and C. tener differ in both karyologic and morphometric attributes. Conversely, C. laucha is a smaller species, more similar in size to C. tener (HeRSHKOVITz 1962). Body size and cranial measurements allow the separation of Brazilian Calomys species into two groups: the callosus group, with large body size species including C. callosus, C. expulsus and Calomys tocantinsi and the laucha group, including the small-sized species $C$. tener and C. laucha.

The Principal Component Analysis showed that $C$. tener is the most distinct of the species analysed by us. Nevertheless, the ANOVA and Canonical Discriminant Analysis significantly separated Calomys tocantinsi from C. expulsus and C. callosus (Fig. 3). Morphological analysis allow the separation of Calomys tocantinsi from C. expulsus and C. tener in the following characters: (1) rostrum breadth similar in size to interorbital region, wider in C. tener and C. expulsus; (2) interorbital region with weakly developed supraorbital ridges against absence of ridges in C. expulsus and C. tener; (3) palatal bridge broad and long but shorter in C. expulsus and C. tener; (4) anterior limit of mesopterigoyd fossa near to the plane of M3 (this distance similar to length of M2) against shorter distance in C. tener and C. expulsus (less than length of M3); (5) length of superior M3 clearly smaller than M2 against minor size differences between M2 and M3 in C. tener and C. expulsus. Calomys 

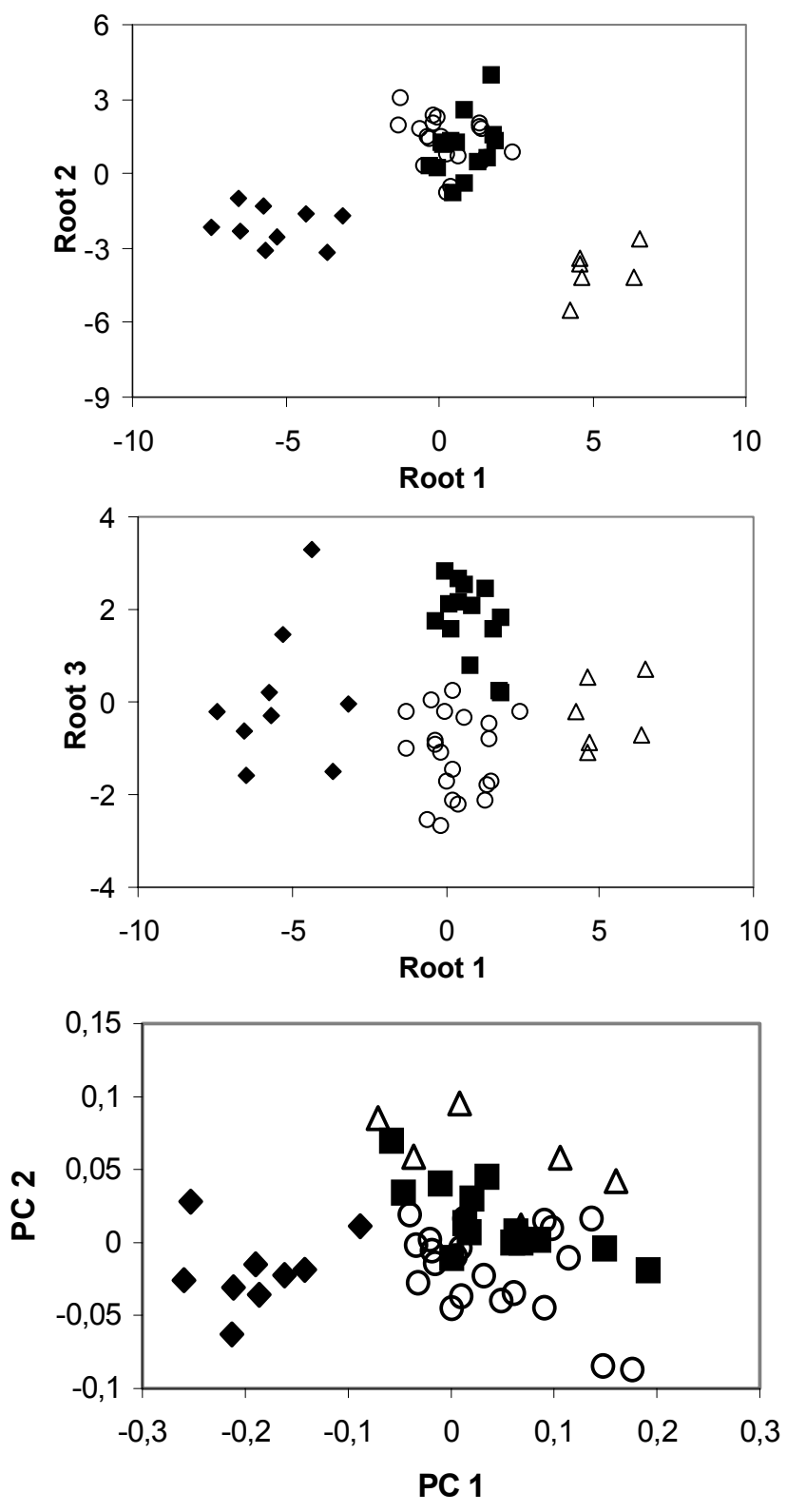

Figure 3. Plot of the (A) first and second, and (B) first and third canonical discriminant functions obtained from the Discriminant Analysis, and (C) PC1 and PC2. The first function comprised $62.7 \%$ of the variance, the second function $26.8 \%$ and the third function $10.45 \%$ of the variance. Eigenvalues for the first, second and third functions are $9.36,4.00,1.56$, respectively. The symbols are: $(\triangle)$ Calomys tocantinsi sp. nov., (O) C. expulsus, (घ) C. callosus and $(\diamond)$ C. tener.

tocantinsi and C. tener also differ from C. expulsus in showing a narrower first superior molar.

However, these three species share many morphological characters, as expected between congeneric species. Their skulls are delicate, with a medium size and narrow rostrum, long incisive foramen, large zygomatic plate relatively to cranium size and with deep zygomatic notch, interorbital region without well developed ridges, interparietal bone as broad as parietal and parapterygoid plate wider than mesopterygoid fossa. In dental characters, these species posses the superior molar row parallel and the anterocone divided by a prominent fold (the anteromedian flexus) into anterolingual and anterolabial conules. In external characters, they share a head-body length higher than tail length and presence of white hairs patch behind ears.

At least four Calomys species occur in the Cerrado of Central Brazil, C. expulsus and C. tener (with $2 \mathrm{n}=66$ ), Calomys tocantinsi (with $2 \mathrm{n}=46$ ) and Calomys sp. (with $2 \mathrm{n}=36$ ). Sympatry of Calomys species is common; C. expulsus and $C$. tener are sympatric at Minas Gerais (Lagoa Santa) and Goiás states and in the Federal District, being both sympatric with Calomys sp. (with $2 \mathrm{n}=36$ ) in Lagoa Santa. In Brazil, all Calomys species are mainly distributed in Cerrado but also occur in Caatinga and in the west border of Atlantic Forest. Calomys sp. (with $2 \mathrm{n}=36$ ) is restricted to Lagoa Santa, state of Minas Gerais. C. expulsus occurs in Caatinga and Cerrado, in the states of Piauí, Pernambuco, Bahia, Goiás, Minas Gerais and in the Federal District. C. tener occurs in the border of Atlantic Forest and in Cerrado, in the states of São Paulo, Minas Gerais, Goiás, Bahia and in the Federal District, Brazil. Calomys tocantinsi sp. nov. (with $2 n=46$ ) is endemic to Cerrado of Central Brazil but can be found in transitional areas between Amazonian rain forest and "cerrado", in the states of Tocantins and Mato Grosso. The distribution of C. callosus and C. laucha in Brazil is not well established; Hershrovitz (1962) restricted the distribution of C. laucha laucha (= Calomys laucha) to other countries rather than Brazil and restricted C. callosus to the southern part of Brazil.

Morphologic, karyologic and biogeographic data supported our opinion that Calomys tocantinsi is a different species, endemic to Cerrado of Central Brazil and allopatric in with other congeneric species.

\section{Voucher specimens and methods}

Calomys tener, C. expulsus, and Calomys tocantinsi specimens were analysed from different Brazilian localities and C. callosus from Bolivia and Paraguay (Fig. 1). All C. tener, C. expulsus (except the specimens from the state of Piauí) were previously karyotyped (Bonvicino \& Almeida 2000).

Calomys callosus - Bolivia, Dept of Santa Cruz: La Hoyada, $30 \mathrm{~km} \mathrm{~S}$ of Valle Grande (male MVZ 134660, female MVZ 134661), Paraguay, Dept of Boqueron: Rio Verde $300 \mathrm{~km}$ NW Villa Hayes by road (female MVZ 145217, males MVZ 145218-220), Dept of Presidente Hayes: $295 \mathrm{~km}$ NW Vila Hayes by road, Chaco Experimental Station (males MVZ 145224-25, 145227-30, 145232, 145236, 145243, females MVZ 145226, 145231, 145233-35, 145237, 145241-42, 145244), 69 km NW Villa Hayes by road $\left(24^{\circ} 40^{\prime} \mathrm{S} 58^{\circ} 04^{\prime} \mathrm{W}\right.$, female MVZ 145221 , male MVZ $145223), 213 \mathrm{~km}$ NW Villa Hayes by road $\left(24^{\circ} 16^{\prime} \mathrm{S} 59^{\circ} 15^{\prime} \mathrm{W}\right.$, male MVZ 145222).

Calomys expulsus - BraziL, Goiás: Fazenda Fiandeiras, 65 $\mathrm{km} \mathrm{SSW}$ of Cavalcante (GPS $14^{\circ} 04^{\prime} \mathrm{S} 47^{\circ} 45^{\prime} \mathrm{W}$, males MN 61583, 61586-87, females MN 61584-85), Pouso Alto, $5 \mathrm{~km} \mathrm{~N}$ of Alto Paraíso (GPS $14^{\circ} 01^{\prime} \mathrm{S} 47^{\circ} 31^{\prime} \mathrm{W}$, females MN 61588-890, Fazenda 
Vão dos Bois, Terezina de Goiás (GPS 1334'29"S 4710'57"W, MN 43031, females MN 43027, 43032, males MN 43028-30, 43033-34, 43036), Morro dos Cabeludos, Corumbá de Goiás (155'ㅇ 48 48'W, sex unknown MN 61576, female MN 61580, males MN 61577-78); Bahia: Fazenda Jucurutu, Jaborandi (GPS $14^{\circ} 10^{\prime} \mathrm{S} 44^{\circ} 33^{\prime} \mathrm{W}$, females CRB 1567, MN 61606); Piauí: São João do Piauí ( $8^{\circ} 21^{\prime} 99^{\prime \prime}$ S $42^{\circ} 14^{\prime} 48^{\prime \prime} \mathrm{W}$, females LBCE 1237, 1245).

Calomys tener - Brazil, Goiás: Fazenda Vão dos Bois, Terezina de Goiás (males MN 43026, 43035), Morro dos Cabeludos, Corumbá de Goiás (males MN 61574, 61579, female MN 61575); São Paulo: Fazenda Fortaleza, Pedreiras $\left(22^{\circ} 43^{\prime} S\right.$ $46^{\circ} 55^{\prime} \mathrm{W}$, female MN 61590, male MN 61591), Campinas ( $22^{\circ} 47^{\prime} \mathrm{S} 47^{\circ} 05^{\prime} \mathrm{W}$, female MN 61605), Fazenda São José, Rio Claro $\left(22^{\circ} 45^{\prime} \mathrm{S} 47^{\circ} 33^{\prime} \mathrm{W}\right.$, male MN 61593), Itirapina $\left(22^{\circ} 15^{\prime} \mathrm{S}\right.$ $47^{\circ} 49^{\prime} \mathrm{W}$, female MN 61592).

Calomys tocantisi - see description.

Skins and skulls of specimens are housed in the Brazilian mammal collections of the Museu Nacional (MN, Rio de Janeiro) and mammal collection of Tocantins University Foundation (ZUT, Porto Nacional, state of Tocantins). MVZ refers to Museum of Vertebrate Zoology specimens, University of California, Berkley. Chromosome preparations were obtained from bone marrow cultures in RPMI 1640, 20\% fetal calf serum, ethidium bromide $(5 \mu \mathrm{g} / \mathrm{ml})$ and colchicine $10^{-6} \mathrm{M}$ for two hours. For morphologic comparisons was took 18 measurements from skull, as defined by BONVICINO \& WeKsLER (1998): Greatest Skull Length (GSL), Condylo-Incisive Length (CIL), Breadth of the Occipital Condyles (BOC), Length of Diastema (LD), Palatal Bridge (PB), Length of Incisive Foramen (LIF), Breadth of Incisive Foramen (BIF), Length of Maxillary Molars (LM), Breadth of First Maxillary Molar (BM1), External Alveolar Breadth (M1M), Cranial height $(\mathrm{CH})$, Rostrum Length (RL), Rostrum Breadth (BRO), Least Interorbital Breadth (LIB), Orbital Length (ORL), Zygomatic Breadth (ZB), Breadth of Braincase (BB), and Breadth of the Zygomatic plate (BZP). External measurements, taken from the skin tags, are headbody length (HB), tail length (T), length of feet with claw (F), maximum length of internal side of ear (E), and weight (W).

Only adult animals (with all teeth erupted and functional) were included in morphometric analyses. Were used 13 of the previously cited measurements (GLS, CIL, BOC, LD, $\mathrm{PB}, \mathrm{LIF}, \mathrm{BIF}, \mathrm{LM}, \mathrm{BM} 1, \mathrm{ORL}, \mathrm{LIB}, \mathrm{ZB}$ and $\mathrm{PB}$ ) in these analyses because only these measurements were available for all specimens. Morphometric analyses did not include the specimens of Calomys expulsus from the state of Piauí. As sexual dimorphism in cranial variables was not detected (Analysis of Variance with significance derived from sequential Bonferroni technique; Rice 1989), males and females were pooled in subsequent analyses. Were evaluated patterns of morphometric differentiation by Analysis of Variance ( $p$ values derived from sequential Bonferroni technique) with Bonferroni test for contrasting means, Canonical Discriminant Analysis, and Principal Component Analysis using pooled within-group covariance matrix of logarithmic variables. All statistical analyses were performed using SAS software 8.0

\section{ACKNOWLEDGMENTS}

We are grateful to S.M. Lindbergh and G.S. Borges for permitting us to collect animals respectively in Vão dos Bois and Beira Rio farm. To J. Marinho and J.A. de Oliveira for permission to study the collection of UnB (Brasília) and MN (Rio de Janeiro); to J.A. de Oliveira for helping us with photographs; and to P.R. Gonçalves reviewed a previous version of this manuscript and provided helpful comments. We are also grateful for F.D. de Avila-Pires for helpful comments. The license for collecting specimens was granting us for Instituto Brasileiro do Meio Ambiente e dos Recursos Naturais Renováveis (IBAMA). Work supported by CNPq/PRONEX.
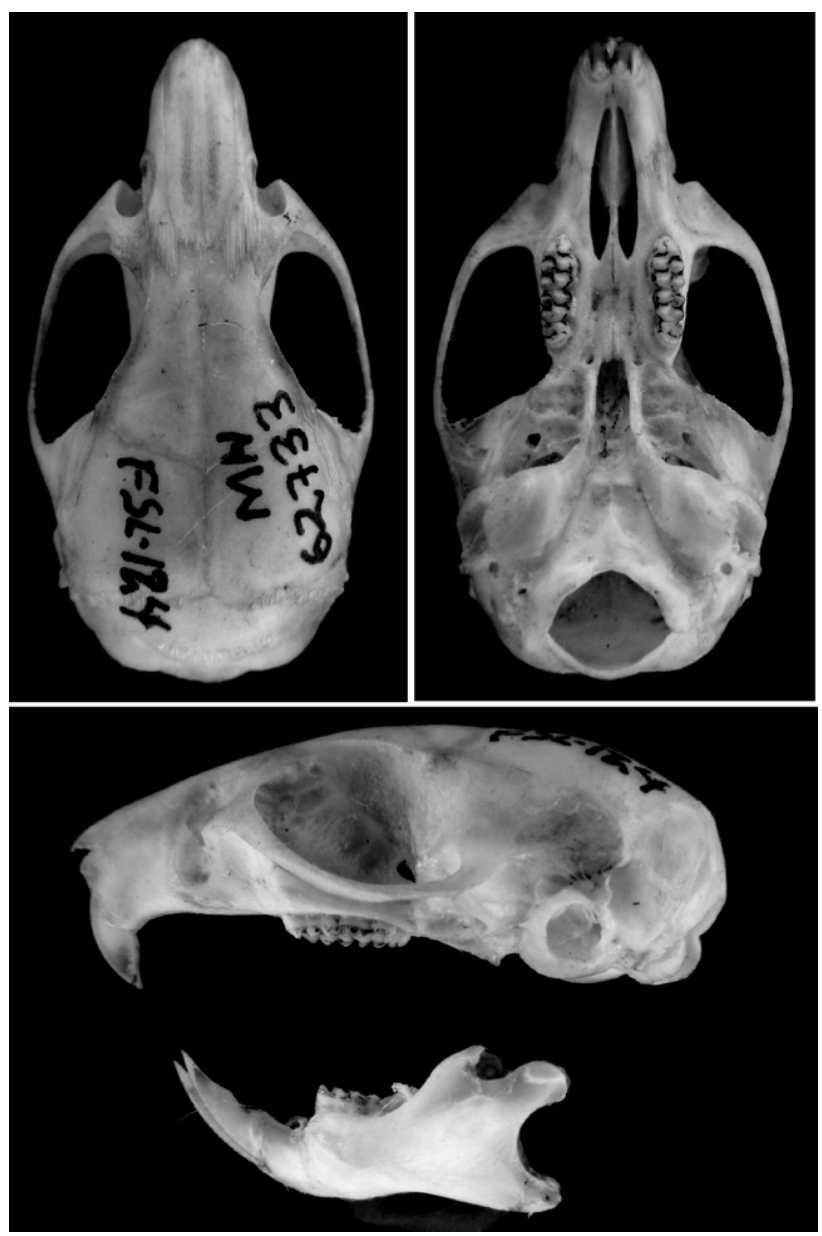

Fig. 4. Dorsal, ventral and lateral view of the skull of the Calomys tocantinsi sp. nov. holotype (MN 62733).

\section{REFERENCES}

Alho, C.J. \& L.A. Pereira. 1985. Population ecology of a cerrado rodent community in Central Brazil. Revista Brasileira de Biologia, Rio de Janeiro, 45:597-609.

Alho, C.J.; L.A. Pereira \& A.C. Paula. 1986. Patterns of habitat utilisation by small mammals population in cerrado biome of Central Brazil. Mammalia, Paris, 50: 447-460. 
BASKIN, J.A. 1978. Bensomys, Calomys, and the origin of the Phyllotini group of Neotropical Cricetines (Rodentia: Cricetidae). Journal of Mammalogy, Povo, 59: 125-135.

Bonvicino C.R. \& F.C. Almeida. 2000. Karyotype, morphology and taxonomic status of Calomys expulsus (Rodentia: Sigmodontinae). Mammalia, Paris, 64 (3): 339-351.

Bonvicino C.R. \& M. Wersler. 1998. A new species of Oligoryzomys (Rodentia, Sigmodontinar) from Central Brazil. Zeitschrift für Säugetierkunde, Jena, 63: 90-103.

Braun, J.J. 1993. Systematics relationships of the tribe Phyllotini (Muridae: Sigmodontinae) of South America. Special Publication Oklahoma Museum of Natural History, Norman: 1-50.

Brum-Zorrilla, N.; G. Hurtado de Catalfo; C. Degiovanangelo; R.L. Wainberg \& T. Gentile de Fronza. 1990. Calomys laucha chromosome (Rodentia, Cricetidae) from Uruguay and Argentina. Caryologia, Florence, 43 (1): 65-77.

Cabrera, A. 1961. Catálogo de los mamíferos de la América del Sur. Revista del Museo Argentino de Ciencias Naturales Bernadino Rivadavia, Buenos Aires, 4: 1-732.

Corach, D.; N.O. Bianchi \& L. Vidal-Rioja. 1988. Characteristics in species of Calomys (Rodentia, Cricetidae). Cytologia, Tokyo, 53: 73-79.

Fagundes, V.; Y. Sato; M.J.J. Silva; F. Rodrigues \& Y. YonenagaYASSUDA. 2000. A new species of Calomys (Muridae, Sigmodontinae) identify by its karyotype. Hereditas, Lund, 133: 195-200.

Gardner, A.L. \& J.L. Patton. 1976. Karyotype variation in Oryzomyine rodents (Cricetinae) with comments on chromosomal evolution in the Neotropical cricetine complex. Occasional Papers Museum Zoology Lousiana State University, Baton Rouge, 49: 1-48.

Gardenal, C.N.; N. Triay De Juarez; M. Gutierrez \& M.S. Sabattini. 1977. Contribuicion al conocimiento de tres especies del genero Calomys (Rodentia, Cricetidae). I. Estudios citogeneticos. Physis, Buenos Aires, 36: 169-178.

Geise, L.; E. Hingst; M. Weksler \& R. Cerqueira. 1996. A new karyotype of Calomys (Rodentia: Sigmodontinae), with taxonomic considerations. Revista Brasileira de Genética, Ribeirão Preto, 19 (Suppl. 3): 102.

Hershrovitz, P. 1962. Evolution of Neotropical Cricetine rodents (Muridae) with special reference to the phyllotine group. Fieldiana Zoology, Chicago, 46: 1-524.

Kasahara, S. \& Y. Yonenaga-Yassuda. 1984. A progress report of cytogenetics data on Brazilian rodents. Revista Brasileira de Genética, Ribeirão Preto, 8: 509-533.

Karimi, Y.; C.R. Almeida \& F. Petter. 1976. Note sur les rongeurs du Nord-est du Brésil. Mammalia, Paris, 40: 257-266.

Lima, J.F.S. \& S. Kasahara. 1999. Cytogenetic studies in specimens of Calomys (Rodentia, Sigmodontinae) from state of Tocantins, Brazil. Genetics and Molecular Biology, Ribeirão Preto, 22 (Suppl. 3): 48.

2001. A new karyotype of Calomys (Rodentia: Sigmodontinae). Iheringia, Série Zoologia, Porto Alegre, 91: 133-136.

Mares, M.A.; K.A. Ernest \& D.D. GetTinger. 1986. Small mammal community structure and composition in the cerrado province of Central Brazil. Journal of Tropical Ecology, Cambridge, 2: 289-300.

Massoia, E.; A. Fornes; R.L. Wainberg \& T.G. DE. Fronza. 1968. Nuevos aportes al conocimiento de lasa species bonaerenses del género Calomys (Rodentia-Cricetidae). Revista de Investigaciones Agropecuarias, Serie 1, Biologia y Producción Animal, Buenos Aires, 5 (4): 63-92

Musser, G.G. \& M. Carleton. 1993. Family Muridae, p. 501755. In: D.E. WiLson \& D.A.M. Reeder (Eds). Mammalian species of the world: a taxonomic and geographic reference. Washington, D.C., Smithsonian Institution Press, $2^{\text {nd }}$ ed., $1206 \mathrm{p}$.

Pearson, O.P. \& J.L. Patton. 1976. Relationships among South American phyllotine rodents based on chromosome analysis. Journal of Mammalogy, Povo, 57: 677-686.

Provensal, M.C. \& J.J. Polop. 1993. Morphometric variation in population of Calomys musculinus. Studies in Neotropical Fauna and Environment, Tübingen, 28: 95-103.

Rice, W.R. 1989. Analyzing tables of statistical tests. Evolution, Lawrence, 43: 223-225.

Salazar-Bravo, J.; J.W. Dragoo; D.S. Tinnin \& T.L. Yates. 2001. Phylogeny and Evolution of the Neotropical Rodent genus Calomys: Inferences from Mitochondrial DNA sequence data. Molecular Phylogenetics and Evolution, San Diego, 20 (2): 173-184.

YonenaGa, Y. 1975. Karyotype and chromosome polymorphism in Brazilian rodents. Caryologia, Florence, 28: 269-286.

Received in 21.X.2002; accepted in 29.V.2003. 